\title{
Photoperiod and delayed implantation in the northern fur seal (Callorhinus ursinus)
}

\author{
J. L. Temte* \\ Marine Science Center, Oregon State University, Newport, Oregon 97365, U.S.A.
}

\begin{abstract}
Summary. An equation for determination of the photoperiod at any given latitude for any given date is presented and used in an analysis of reproductive timing in the northern fur seal in which there is an obligatory delay of implantation. Fur seals breeding on San Miguel Island, California $\left(33^{\circ} \mathrm{N}\right)$ displayed a mean date of parturition that was 14 days earlier $(P<0.001)$ than that of the parent stock on the Pribilof Islands, Alaska $\left(57^{\circ} \mathrm{N}\right)$. Previous studies have shown that changes occur in the corpus luteum, in follicles in the ovary containing the corpus luteum, in concentrations of plasma progesterone and oestradiol- $17 \beta$, and in the uterine lining when there is a mean photoperiod of $12.5 \mathrm{~h} /$ day. This photoperiod occurs at both locations at 62 days after the mean dates of parturition, and may act as a cue for the initiation of implantation in these seals.
\end{abstract}

\section{Introduction}

In the reproductive cycle of the northern fur seal (Callorhinus ursinus) there is a 4-month delay of implantation. Viewed as obligatory in most pinniped species, delayed implantation allows about 8 months for fetal development after implantation and maintains precise reproductive timing, even though oestrus occurs shortly after parturition in the otariids, and after the cessation of lactation in phocid seals (Boshier, 1981). Female northern fur seals give birth to pups an average of 0.8 days after returning to colony sites (Peterson, 1965; Bigg, 1984). Although oestrus and copulation occur about 7 days after parturition, implantation is not expected until 120 days after copulation (Craig, 1964; Delong, 1982). Females typically remain at the colony site and in adjacent waters until pups are weaned at 4 months before starting a pelagic migration (Peterson, 1968). Photoperiod, through an effect on pineal gland secretion, has been suggested as a possible exogenous cue for the initiation of implantation in the northern fur seal (Keyes, Wurtman, Elden, Chou \& McGuire, 1971; Elden, Keyes \& Marshall, 1971; review by Daniel, 1981). However, an experimental study of female fur seals kept in different light regimens for up to 5 days by Daniel (1981) failed to produce any conclusive results.

Peterson, LeBoeuf \& Delong (1968) reported that northern fur seals, initially tagged as pups in Alaska $\left(57^{\circ} \mathrm{N}\right)$, were breeding on San Miguel Island, California $\left(33^{\circ} \mathrm{N}\right)$. The present study examined the differences in reproductive timing and photoperiod regimens present during the period between parturition and implantation for northern fur seals at San Miguel Island, California, and the Pribilof Islands, Alaska.

\section{Materials and Methods}

Data consisting of the number of pups born per day during the 1979 pupping season at Adams Cove, San Miguel Island, California, and East Reef Rookery, St George Island, Pribilof Islands,

* Present address: University of Wisconsin Medical School, MSC 4285, 1300 University Avenue, Madison, Wisconsin 53706, U.S.A. 
Alaska, were obtained from the National Marine Mammal Laboratory. These data were used to calculate the mean and variance of parturition dates at each location. Because the variances were not significantly different, the means were compared using Student's $t$ test.

The analysis of the effect of photoperiod on reproductive timing in a wide ranging species such as the fur seal can be greatly facilitated if the photoperiod can be easily calculated from a set of latitudes and dates. Photoperiod (P) in h/day can be described in terms of the date (D) and latitude in degrees $(\mathrm{L})$ by the following equation:

$$
P=24.00-7.64(\arccos [\tan (0.01745 \mathrm{~L}) \tan (0.00455 \mathrm{D})]) \mathrm{h} / \mathrm{day}
$$

where the date (D) is given in terms of the sequential day number (d) from the winter solstice, 21 December, by $d-91$, for $0 \leqslant d \leqslant 182$ and $273-d$, for $182<d \leqslant 365$. Latitudes in the southern hemisphere are considered negative. The equation is valid in the range of latitudes $\left(-66 \cdot 2^{\circ}\right.$ to $\left.66 \cdot 2^{\circ}\right)$ between the Antarctic and Arctic Circles. This equation was formulated through trigonometric construct (J. L. Temte, unpublished observations). Photoperiods were calculated for the 21 st day of each month from December to June at latitudes of $30^{\circ} \mathrm{N}, 40^{\circ} \mathrm{N}, 50^{\circ} \mathrm{N}$ and $60^{\circ} \mathrm{N}$. Comparisons of these values of photoperiod to values from meteorological tables (List, 1971) were made to verify the equation. The equation yielded accuracies of at least $86 \%$, with mean accuracy of $96 \%$ over the range from $30^{\circ} \mathrm{N}$ to $60^{\circ} \mathrm{N}$. There was a general trend for an increase in accuracy with a decrease in latitude. Analysis of the timing of births in the northern fur seal provides an example of the utility of such an equation.

The photoperiod at parturition and for each subsequent day up to 70 days post partum was calculated for each birth. The mean and variance of photoperiods were then determined for the two locations on each day, relative to parturition, until 70 days post partum. Also, the annual photoperiod cycles at San Miguel and St George Islands were constructed by calculating $\mathbf{P}$ at intervals of 10 days for 370 days.

\section{Results}

The mean dates of parturition for the 1979 pupping season were calculated from 831 and 433 births on San Miguel and St George Islands, respectively (Text-fig. 1). The mean date of parturition was

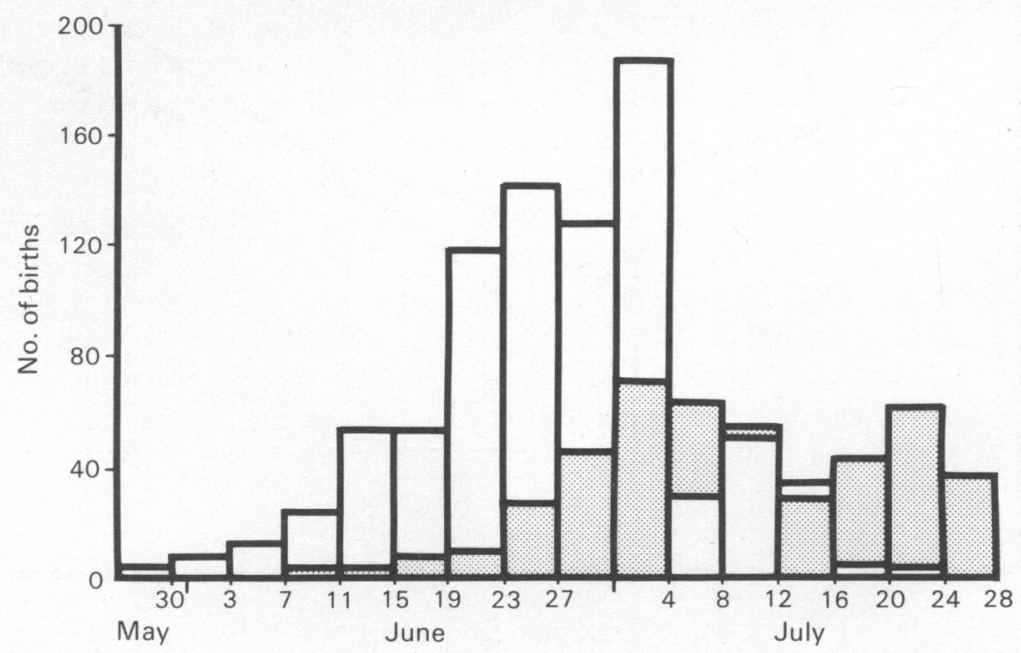

Text-fig. 1. Number of northern fur seal pups born per 4-day period at Adams Cove, San Miguel Island (unshaded), and East Reef Rookery, St George Island, Pribilof Islands (shaded) in 1979. 
26 June at San Miguel and 10 July at St George Island. This 14-day difference in the timing of births is significant ( $P<0 \cdot 001$, Student's $t$ test). The variances were not significantly different (Table 1). These results are similar to the 10-year mean date of parturition of 24 June for fur seals at San Miguel Island (Delong, 1982) and the 7 July mean date of parturition on St Paul Island in the Pribilofs (Bauer, Peterson \& Scheffer, 1964).

Table 1. Timing of births of northern fur seals on San Miguel Island and St George Island

\begin{tabular}{lcc}
\hline & $\begin{array}{c}\text { San Miguel Island } \\
\left(33^{\circ} \mathrm{N}\right)\end{array}$ & $\begin{array}{c}\text { St George Island } \\
\left(57^{\circ} \mathrm{N}\right)\end{array}$ \\
\hline No. of births & 831 & 433 \\
First birth & $28 \mathrm{May}$ & $10 \mathrm{June}$ \\
Last birth & $23 \mathrm{July}$ & $26 \mathrm{July}$ \\
Mean date of birth & $26 \mathrm{June}$ & $10 \mathrm{July}$ \\
Variance & $103 \cdot 86$ & 107.75 \\
Standard deviation & $10 \cdot 19$ days & 10.38 days \\
Standard error & 0.35 days & 0.50 days \\
\hline
\end{tabular}

The annual cycles of photoperiod for San Miguel and St George Islands were referenced to the mean date of parturition at each location (Text-fig. 2). At $33^{\circ} \mathrm{N}$ latitude photoperiod varies between 14.2 and $9.8 \mathrm{~h} /$ day; at $57^{\circ} \mathrm{N}$ latitude it varies between 17.7 and $6.2 \mathrm{~h} /$ day.

Comparison of the mean photoperiods at sequential days referenced to individual dates of parturition reveals that at 62 days post partum seals at both locations are exposed to a mean photoperiod of $12.5 \mathrm{~h}$ /day (Table 2). Photoperiods at 62 days post partum range from 11.9 to 13.2 $\mathrm{h} /$ day at San Miguel Island, and from 11.7 to $14.2 \mathrm{~h} /$ day at St George Island.

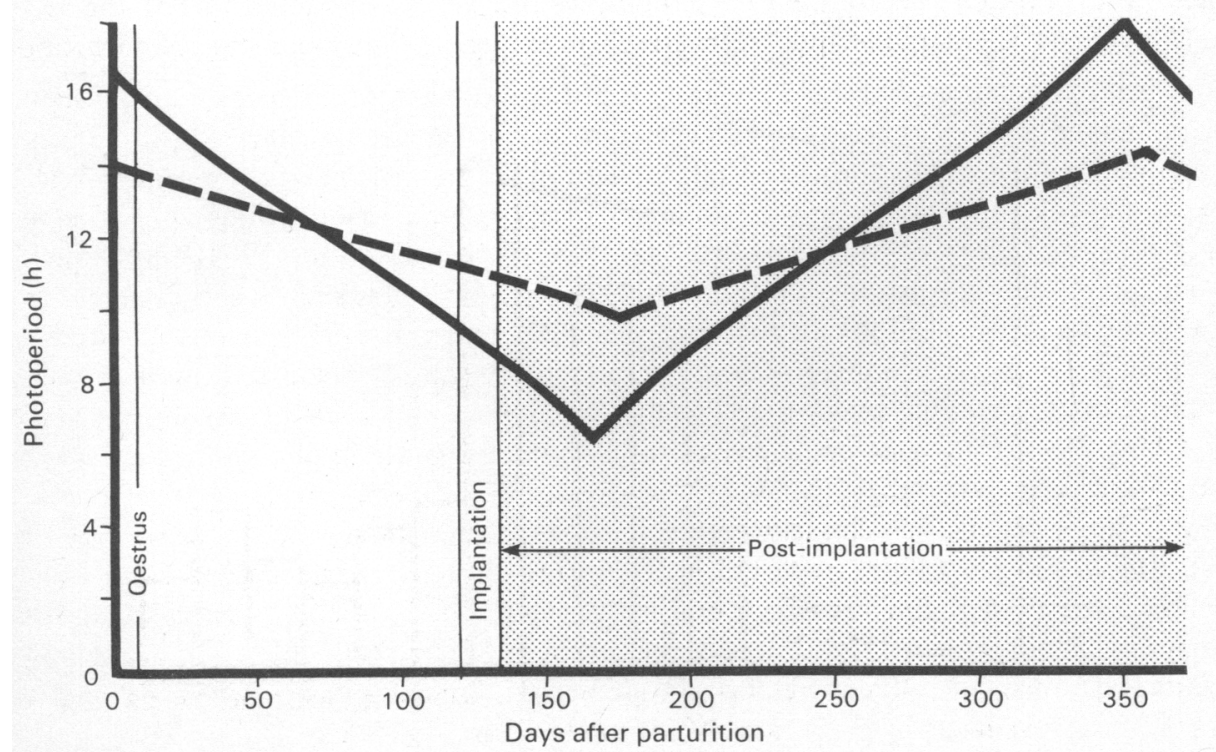

Text-fig. 2. The annual cycles of photoperiod as referenced to the mean dates of parturition for northern fur seals at San Miguel Island, California, $33^{\circ} \mathrm{N}$ (broken line), and St George Island, Alaska, $57^{\circ} \mathrm{N}$ (solid line). Also shown are the approximate times of oestrus and implantation. 
Table 2. Photoperiod at 62 days post partum based on births of northern fur seals at San Miguel Island and St George Island

\begin{tabular}{lcc}
\hline & $\begin{array}{c}\text { San Miguel Island } \\
\left(33^{\circ} \mathrm{N}\right)\end{array}$ & $\begin{array}{c}\text { St George Island } \\
\left(57^{\circ} \mathrm{N}\right)\end{array}$ \\
\hline $\begin{array}{l}\text { No. of births } \\
\text { Photoperiod at 62 days }\end{array} \quad 831$ & 433 \\
$\quad$ post partum (h/day) & & \\
$\quad$ Minimum & 11.93 & 11.68 \\
$\quad$ Maximum & 13.22 & 14.19 \\
$\quad$ Mean & 12.53 & 12.54 \\
Variance & 0.04 & 0.31 \\
Standard deviation (h/day) & 0.21 & 0.56 \\
Standard error (h/day) & 0.01 & 0.03 \\
\hline
\end{tabular}

\section{Discussion}

The presence of a 2-week advance in timing of births for San Miguel Island seals is suggestive of some latitudinal effect, perhaps similar to that reported by Schusterman, Kang, Andrews, McDonald \& Ballou (1982) for captive California sea lions, and by Bigg (1969) for Pacific harbour seals along the west coast of North America. This is especially appealing in light of the Pribilof Island contribution to the original San Miguel Island population. Spotte \& Adams (1981) reported that the timing of births in captive female fur seals at Mystic, Connecticut, was not affected by latitudinal conditions, specifically photoperiod, different from those of the natural range. However, their methods, based upon the estimated birth dates of only 6 aborted fetuses, may not have been robust enough to identify a difference in timing of less than 14 days.

The $12.5 \mathrm{~h}$ /day photoperiod lies within a 'window of reproductive timing' that exists after parturition and before implantation (unshaded area in Text-fig. 2), and while female fur seals are still at their colony site. It is during this period that an exogenous cue, such as a specific photoperiod, could regulate the reproductive timing of northern fur seals through initiation of oestrus or initiation of an implantation sequence.

Studies of the reproductive physiology of female northern fur seals have been limited to the Pribilof Island populations. At this location the $12.5 \mathrm{~h} /$ day photoperiod occurs on 11 September. Although lacking a major reproductive event, mid-September is characterized by changes in the ovary containing the recently formed corpus luteum, in the concentrations of plasma progesterone and oestradiol-17 $\beta$, and in the uterine lining. Corpus luteum inactivation with a decrease in secretory function occurs in mid-August (Craig, 1964). However, Craig (1964) and Daniel (1971) report an increase in corpus luteum diameter between samples taken in early August and late September. A recurrence of follicular activity was noted by Craig (1964) following corpus luteum inactivation, and a peak of follicular activity was reported by Pearson \& Enders (1951) before implantation. Also, the first ovulation of nulliparous female fur seals occurs during September (Craig, 1964). Plasma progesterone concentration increases before implantation from a low value after oestrus in early September (Daniel, 1975). Oestradiol-17 $\beta$ concentrations are also low at this time but a surge occurs immediately before the reactivation of the blastocyst in late October (Daniel, 1974). Daniel (1971) reported that uterine protein, while showing no qualitative differences, more than doubled in concentration during the period between early August and late September. At about the same time the nuclei of uterine epithelial cells change from a granular to a vesicular appearance, and adventitial vasculature becomes more apparent within the uterine wall (Craig, 1964), as expected in preparation for implantation.

The photoperiod at the time that these changes are seen in Pribilof Island fur seals occurs 2 weeks earlier at San Miguel Island, and may explain the latitudinal difference in the timing of births between these locations. A decrease in photoperiod has been shown to affect the timing of 
implantation in other carnivores. Canivenc \& Bonnin (1981) reported that an artificial decrease in photoperiod and temperature could trigger premature implantation in the European badger (Meles meles) by as much as 6 months. The absence of uterine protein changes and implantation in Daniel's (1981) study of northern fur seals kept in different light regiments may have been due to the short (5-day) exposure to an altered photoperiod. It is suggested that a specific photoperiod occurring at about 62 days after parturition (or 65 days before implantation) acts to synchronize the timing of parturition in northern fur seals at a given latitude, presumably by triggering a sequence of changes in the uterus that allows for the activation and implantation of the blastocyst.

I thank A. Temte of the University of Wisconsin and M. Temte of Purdue University for reviewing the photoperiod equation; B. Delong, B. Antonelis, and R. Gentry of the National Marine Mammal Laboratory for generously supplying data; B. Mate, R. Brown, S. Spielvogel and J. Shenker for comments and review; and N. Brown and L. Krasnow for technical assistance.

\section{References}

Bauer, R.D., Peterson, R.S. \& Scheffer, V.B. (1964) Age of northern fur seal at completion of its first molt. $J$. Mammal. 45, 299-300.

Bigg, M.A. (1969) Cline in the pupping season of the harbour seal, Phoca vitulina. J. Fish. Res. Bd Can. 26, $449-455$.

Bigg, M.A. (1984) Stimuli for parturition in northern fur seals (Callorhinus ursinus). J. Mammal. 64, 333-336.

Boshier, D.P. (1981) Structural changes in the corpus luteum and endometrium of seals before implantation. J. Reprod. Fert., Suppl. 29, 143-149.

Canivenc, R. \& Bonnin, M. (1981) Environmental control of delayed implantation in the European badger (Meles meles). J. Reprod. Fert., Suppl. 29, 25-33.

Craig, A.M. (1964) Histology of reproduction and the oestrus cycle in the female fur seal, Callorhinus ursinus. J. Fish. Res. Bd Can. 21, 773-818.

Daniel, J.C., Jr (1971) Growth of the preimplantation embryo of the northern fur seal and its correlation with changes in uterine protein. Devl Biol. 26, 316328.

Daniel, J.C., Jr (1974) Circulating levels of oestradiol$17 \beta$ during early pregnancy showing an oestrogen surge preceding implantation. J. Reprod. Fert. 37, $425-428$.

Daniel, J.C., Jr (1975) Concentration of circulating progesterone during early pregnancy in the northern fur seal, Callorhinus ursinus. J. Fish. Res. Bd Can. 32, 65-66.

Daniel, J.C., Jr (1981) Delayed implantation in the northern fur seal (Callorhinus ursinus) and other pinnipeds. J. Reprod. Fert., Suppl. 29, 35-50.

Delong, R.L. (1982) Population biology of northern fur seals at San Miguel Island, California. Ph.D. dissertation, University of California, Berkeley.
Elden, C.A., Keyes, M.C. \& Marshall, C.E. (1971) Pineal body of the northern fur seal (Callorhinus ursinus): a model for studying the probable function of the mammalian pineal body. Am. J. vet. Res. 32, 639-647.

Keyes, M.C., Wurtman, J., Elden, C.A., Chou, C. \& McGuire, R. (1971) Seasonal fluctuations of hydroxyindole levels in the pineal gland of the northern fur seal. J. Wildlife Dis. 7, 235, Abstr.

List, R.J. (1971) Smithsonian Meteorological Tables, Sixth Revised Edition. Smithsonian Miscellaneous Collections, Vol. 114, 527 pp. Smithsonian Institution Press, Washington, D.C.

Pearson, A.K. \& Enders, R.K. (1951) Further observations on the reproduction of the Alaska fur seal. Anat. Rec. 111, 695-712.

Peterson, R.S. (1965) Behavior of the northern fur seal. Ph.D. dissertation, Johns Hopkins University, Baltimore, Maryland.

Peterson, R.S. (1968) Social behavior in pinnipeds with particular reference to the northern fur seal. In The Behavior and Physiology of Pinnipeds, pp. 3-53. Eds R. J. Harrison, R. C. Hubbard, R. S. Peterson, C. E. Rice \& R. J. Schusterman. Appleton, New York.

Peterson, R.S., LeBoeuf, B.J. \& Delong, R.L. (1968) Fur seals from the Bering Sea breeding in California. Nature, Lond. 219, 899-901.

Schusterman, R., Kang, I., Andrews, B., McDonald, C. \& Ballou, D. (1982) Reproduction in captive California sea lions: photoperiod and annual timing of the birth season. In Marine Mammal Information, p. 42, Abstr. Ed. B. R. Mate. Oregon State University Sea Grant College Program, Corvallis, Oregon.

Spotte, S. \& Adams, G. (1981) Photoperiod and reproduction in captive female northern fur seals. Mammal Rev. 11, 31-35. 